Article

\title{
Sustainability Metrics for Housing and the Thermal Performance Evaluation of a Low-Cost Prototype Made with Poly (Ethylene Terephthalate) Bottles
}

\author{
Flavio Roberto Ceja Soto ${ }^{1}$, José de Jesús Pérez Bueno ${ }^{1, * \mathbb{D}}$, Maria Luisa Mendoza López ${ }^{2}$, \\ Martha Elva Pérez Ramos ${ }^{2}$, José Luis Reyes Araiza ${ }^{2,3}{ }^{\circledR}$, Rubén Ramírez Jiménez ${ }^{3}$ and \\ Alejandro Manzano-Ramírez ${ }^{4}$ \\ 1 Center of Research and Technological Development in Electrochemistry, S. C., \\ Technologic Park Queretaro-Sanfandila, Pedro Escobedo, C.P. 76703 Queretaro, Qro, Mexico \\ 2 National Technologic of Mexico, Queretaro Campus, Technologic Av., Center C.P. 76000 Queretaro, \\ Qro, Mexico \\ 3 Autonomous University of Queretaro. Faculty of Engineering, University Center Hill of the Bells, \\ C.P. 76010 Queretaro, Qro, Mexico \\ 4 Center of Research and Advanced Studies of the National Polytechnic Institute, Queretaro Unit, \\ Northwestern Av. \#2000, Real of Juriquilla. C.P. 76230 Santiago of Querétaro, Qro, Mexico \\ * Correspondence: jperez@cideteq.mx; Tel.: +52-442-2116090; Fax: +52-442-2116001
}

Received: 21 March 2019; Accepted: 19 July 2019; Published: 24 July 2019

\begin{abstract}
The scope of this work covers a proposal for the implementation of sustainable, low-cost, environmentally friendly, and affordable housing for low-income people. This paper aims to address the current housing issues, namely that many people lack decent housing and that the built houses are usually of a poorly sustainable nature. The work consists of three main parts: an evaluation of housing sustainability, measurement of parameters related to their internal comfort and a simulation of thermal enclosure with the COMSOL Multiphysics ${ }^{\circledR}$ software. An important objective is to propose a sustainability assessment format, which, besides being explained in detail, is presented in a percentage scale for ease of understanding. This work seeks a methodology for evaluating the level or degree of sustainability for the construction and inhabitation stages of housing. Using a prototype constructed with polyethylene terephthalate (PET) bottles, temperature and humidity were measured. There was a contrasting behavior of these two parameters, which tended towards an inverse behavior, except on cloudy or rainy days. The roof of the prototype contained some waste materials that provided thermal insulation: galvanized steel, polyethylene bags for upcycling as waterproofing, PET bottles, soil and endemic plants (green roof). The results obtained in the simulation are in accordance with the real internal behavior of the prototype.
\end{abstract}

Keywords: sustainable housing; building materials; recycling; interior comfort; upcycling; endemic plants; green roofs

\section{Introduction}

Housing is one of the primary needs of human beings, and is currently a pressing need that is directly associated with population growth both on a local and global scale. It is also a problem with a high ecological impact, as much in terms of the occupation of spaces needed for residential developments as for the use of large quantities of materials for construction. Moreover, there is a concern about the direct and indirect impacts of the extraction, processing and transport of these materials. Constructive innovation is a major solution to the needs of the human organism, which has by various means provided for itself since the era of Homo erectus about half a million years ago, 
according to Hadfield [1]. Later, construction methodology evolved, leading to the sustainability tendency which aims at using renewable materials available from the surrounding areas and measuring their life cycles, as shown by Mun and Choi [2]. Currently, there is a boom in the use of building materials that were used in past times, such as stone façades, stucco, blocks of compressed earth and organic materials such as wood and bamboo [3-9]. The latter are rapidly renewable, and have useful properties based on their weight-resistance relationship that are comparable with steel or new high-tech fibers [10-12]. Many other vegetal alternative materials have been used, such as cork [13] and Arundo donax [14].

Another example is the use of adobe, which is no longer used in urban construction but is known to have properties of interest, such as an excellent coefficient of thermal conductivity that allows internal comfort. The disadvantage of adobe is its deterioration in the face of weathering factors such as rain and wind. There are, however, a few innovations that provide greater resistance in adobe stabilization, such as a cover of latex, lime or fermented fertilizer mixtures [15-17].

In this work, a prototype of a room for a house of social interest was built using some recycled materials. Polyethylene terephthalate (PET) bottles or waste soft-drink containers were used to close the space of the room (walls). These bottles were not processed (mechanically or chemically), to avoid energy consumption in their recycling [18]. Several works have reported the use of PET as a recycled material in related research on construction materials such as concretes, mortars, and so on, adding it to mixtures of such materials [19-25]. In addition, this prototype served as a reference in evaluating the sustainability of homes, according to different parameters that influence the sustainability metrics proposed in this work.

This work proposes an evaluation of the prototype characteristics of both existing structures as well as those in planning, which include thermal, acoustic and electromagnetic insulation, environmental and structural humidity and gases (volatile organic compounds, oxygen, methane, and carbon dioxide). This also includes the affectation of these parameters by modifications made to housing surfaces, both covered and not covered by painting and waterproofing. This work shows only the results of the consensual values assigned to the different factors for the metrics of sustainability and thermal behavior of a housing prototype built using PET bottles. The evaluation of the rest of the indicated factors is relevant in the case of inhabited houses.

The work seeks to identify and improve practices that quantify the degree of sustainability that a construction work may have. Based on the information obtained from the prototypes, a COMSOL Multiphysics ${ }^{\circledR}$ simulation of thermal insulation was made for a prototype intended to represent sustainable housing. This software has, among others, the advantages of coupling different physical phenomena and integrally making the simulation by handling the thermal and the acoustic modules.

Castañeda [26] argues that the construction industry is one of the sectors with the highest contribution to environmental pollution. Therefore, concern in the field of construction and sustainable development has grown. Various social organizations have been consolidated, from small groups to large companies, with the purpose of proposing sustainable housing projects that involve some sustainable characteristics in their construction. The present work, associated with this theme, seeks to outline quantifiable elements that can allow different prototypes that to be considered "sustainable".

The life cycle assessment (LCA) methodology is meant to assess the impacts of primary energy input (PEI) and greenhouse gas emissions throughout the whole life cycle of a product, including buildings [27]. LCA follows the ISO 14040-14044 (ISO 2006a,b), and can be calculated using software such as SimaPro [28]. A cradle-to-grave LCA applied to buildings is a complex process, with some prioritizing the evaluation of carbon dioxide-equivalent emissions [29] and possibly including others such as land use, acidification, eutrophication, ozone depletion, resource depletion and human toxicity [30-32]. Some works were extended to include life cycle assessment (LCA), life cycle energy analysis (LCEA) and life cycle cost analysis (LCCA) studies [33]. There is an absence of common criteria among the reported studies, such as a common methodological structure; shared parameters 
for construction, transportation, consumption of water and energy, maintenance, waste destination; or the practical application of LCA in different regional typologies [29,34].

Currently, there are few quantitative systems that adequately assess the sustainability of homes throughout their life cycle [35], especially in terms of actual circumstances and regional interests. This is because building design does not consider operating costs and environmental impacts of systems associated with operation in the life cycles of the buildings. Usually, measurement of sustainability can be conducted in large building projects (such as Leadership in Energy and Environmental Design $\left(\right.$ LEED $\left.^{\circledR}\right)$ in the United States [36]) or for real estate developments (such as CONAVI in Mexico [37]). Therefore, this work seeks to discover a methodology for evaluating the level or degree of sustainability of building designs.

\section{Materials and Methods}

\subsection{Materials Used in Construction}

The prototype room had an area of about $9 \mathrm{~m}^{2}$. In building the walls of the prototype, 5000 PET bottles of $600 \mathrm{~mL}$ in size, filled with sand from the site, were used (Figure 1). These were placed on the conventionally constructed foundations. The bottles had a mooring with an annealed mesh (Figure 2). Then, there was a layer of mortar repellant. Finally, a coat of white cement and marble powder was applied to confer a white aesthetic finishing appearance, to avoid an extra finish such as paint or waterproofing. The roof had six sheets of galvanized steel overlapping their extremes, followed by a cover of the recycled high-density polyethylene bags commonly used in supermarkets. In this case, they were used in the sense of upcycling them as a waterproof layer. The polyethylene bags constitute a high pollution source and were overlapped to form a continuous plastic layer on the roof. The prototype roof included a double layer of about 1000 PET bottles, which were uncovered and empty; all other PET bottles with irregular shapes and different sizes that were not suitable for the walls were used. As a third layer, another layer of used bags was used. A fourth layer used the cardboard waste from the packages of construction materials. The next layer was made with the site soil. The top layer was generated using endemic vegetation from the site of construction. The latter was intended for two purposes: first, for conferring a cover that provides shade; and second, to realize the original idea of not altering the landscape from a top view, an aerial view or a satellite perspective.

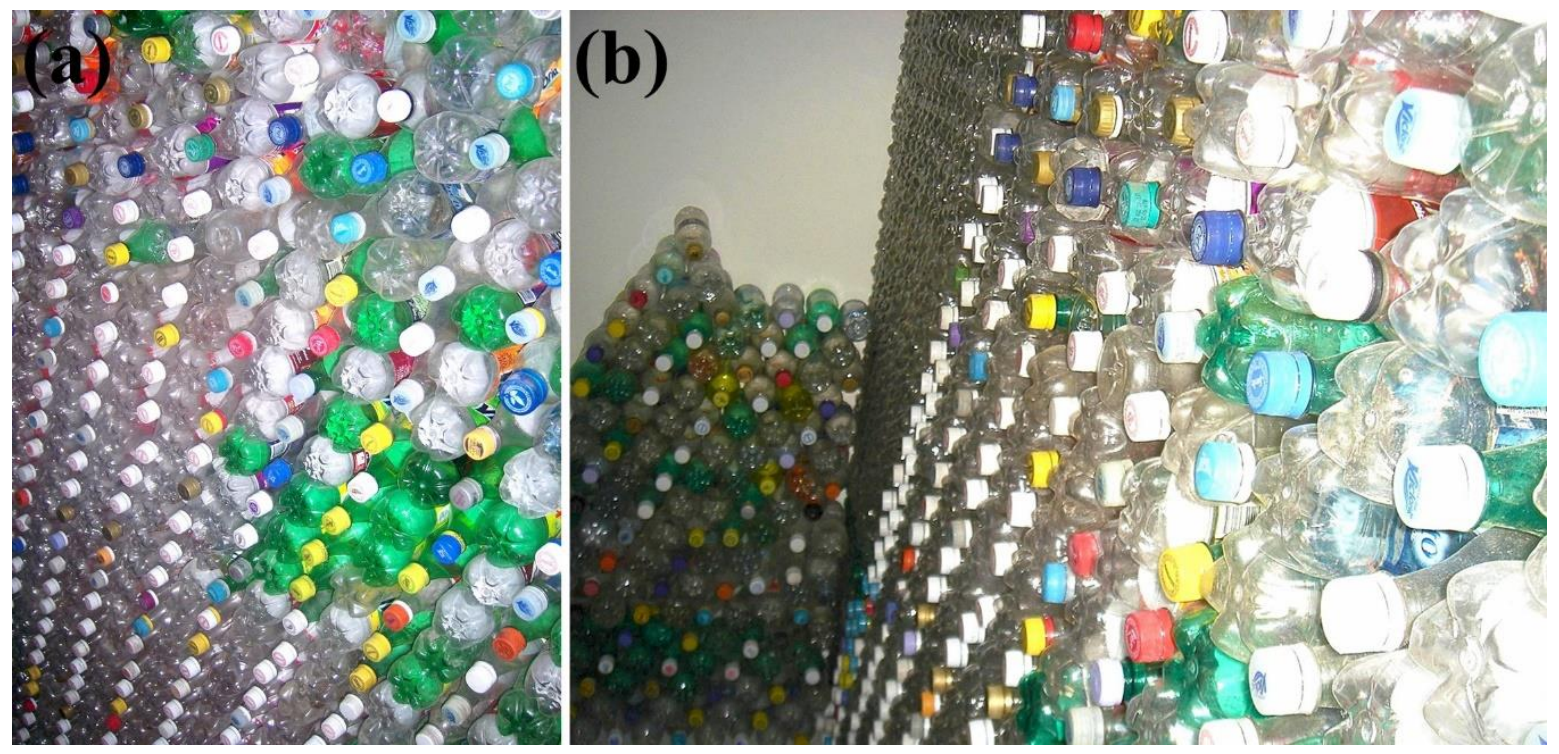

Figure 1. (a,b) Two different views of the collected polyethylene terephthalate (PET) bottles, under storage, before building the prototype. 

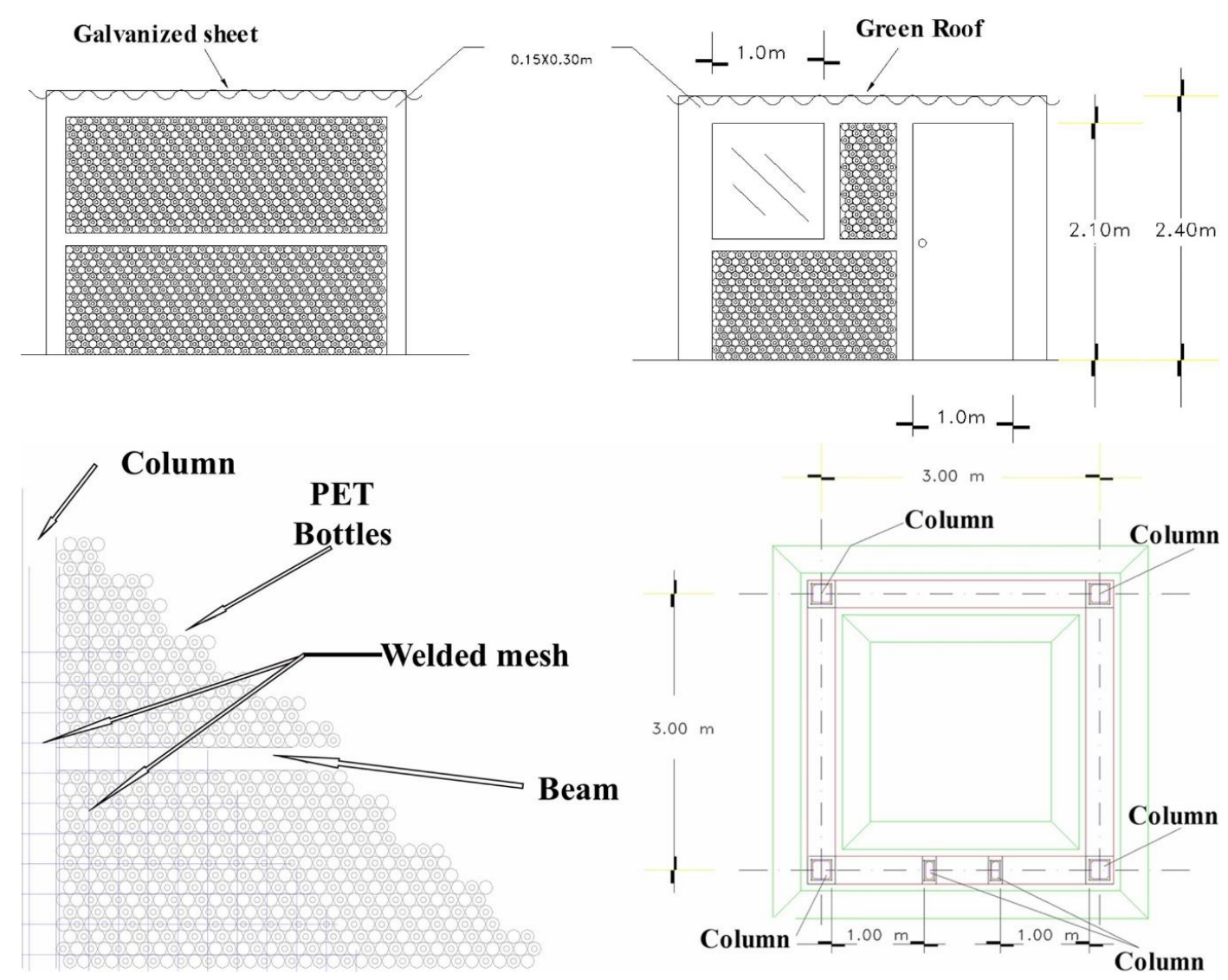

Figure 2. The structure planes proposed before constructing the housing.

\subsection{Instruments and Software}

The instruments used in this work include a thermographic camera, PCE-TC 3 model, brand PCE-Group Ibérica SL. Also, temperature and humidity sensors, brand Thermotracker.

The simulation was conducted using COMSOL Multiphysics ${ }^{\circledR}$ software with the versions 3.5 and 4.2.

\subsection{Methods}

\subsubsection{Thermic Simulation}

The simulation was done using COMSOL Multiphysics ${ }^{\circledR}$ software version 3.5 and 4.2, employing the thermal transfer module and the earth science module. The methodology followed in this simulation consisted of the following:

- A compatible file extension of the desired structure was imported to the software, or a direct drawing of the structure was simulated.

- The specific conditions of the structure and type of material were specified in the walls, windows, doors, ceiling and foundation.

- The border and the initial conditions were established for the entire structure, sectioning the parts of the house, if necessary, to set different circumstances.

- $\quad$ The simulated system was solved.

\subsubsection{Measurement of Internal and External Parameters}

Temperature and humidity measurements were carried out with Thermotracker sensors, located in strategic areas of the evaluated prototypes. 
With the PCE-TC 3 thermal imager, thermographic images were taken, showing the temperature contrasts and the behavior of the materials used.

\section{Results and Discussion}

\subsection{Assessment of the Degree of Sustainability}

Below is the proposal for sustainability indicators or metrics. It should be noted that this proposal was applied to the prototype in its construction phase, but not to the performance of the house, because it was not an inhabited construction. The life of a building consists of three stages: construction, operational phase, demolition and waste treatment [38]. In this work, the first two stages were considered. No measurement indicators of the demolition stage were raised due to the short period of the evaluation process. However, it has been reported in other literature that, during this stage, a ratio of 80:20 solid waste is generated in proportion to that of construction [18].

Each stage contained important aspects and these, in turn, were sectioned by assigning values that allowed us to obtain total scores, as shown in Tables 1 and 2.

Table 1. The weight for the evaluation of the degree of sustainability for the construction stage of the housing.

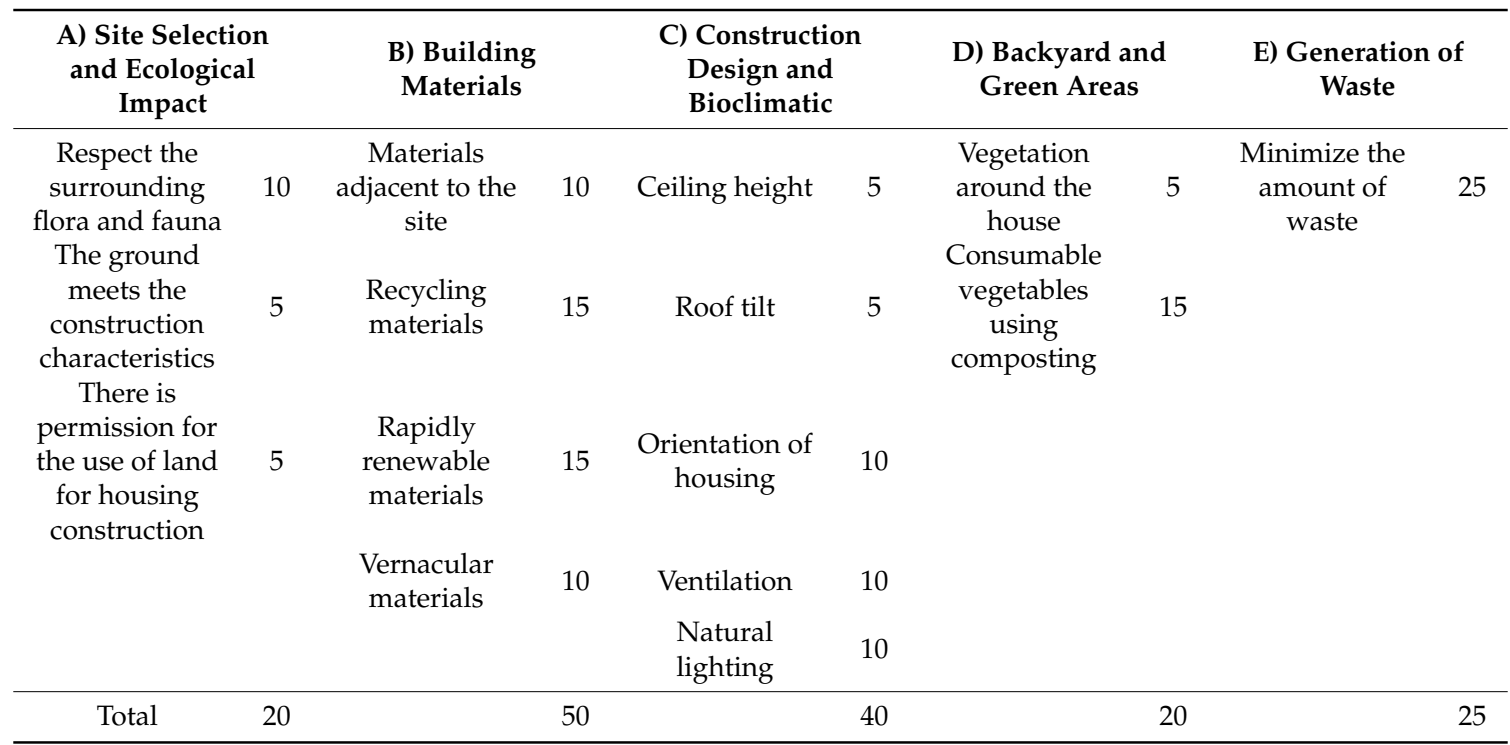

Table 2. The weight for the evaluation of the degree of sustainability for the inhabitation stage of the housing.

\begin{tabular}{|c|c|c|c|c|c|c|c|c|c|}
\hline $\begin{array}{l}\text { (A) Energy } \\
\text { Efficiency }\end{array}$ & & $\begin{array}{l}\text { (B) Care of the } \\
\text { Water Resourc }\end{array}$ & & $\begin{array}{l}\text { (C) Separation, } \\
\text { Disposal, and } \\
\text { Exploitation of } \\
\text { Waste }\end{array}$ & & $\begin{array}{l}\text { (D) Internal } \\
\text { Comfort }\end{array}$ & & \multicolumn{2}{|c|}{$\begin{array}{l}\text { (E) Fuel Used and } \\
\text { Emissions } \\
\text { Generated }\end{array}$} \\
\hline \multirow[t]{4}{*}{$\begin{array}{l}\text { Use of solar or } \\
\text { other } \\
\text { renewable } \\
\text { energy }\end{array}$} & 35 & $\begin{array}{c}\text { Rainwater } \\
\text { harvesting and } \\
\text { reuse }\end{array}$ & 15 & Composting & 5 & Acoustics & 10 & $\begin{array}{l}\text { Natural Gas or } \\
\text { LP Gas }\end{array}$ & 10 \\
\hline & & $\begin{array}{l}\text { Separation of } \\
\text { gray water and } \\
\text { sewage }\end{array}$ & 15 & $\begin{array}{l}\text { Separation of } \\
\text { PET, glass, } \\
\text { paperboard, } \\
\text { paper, } \\
\text { aluminum }\end{array}$ & 15 & Temperature & 10 & Biogas & 15 \\
\hline & & $\begin{array}{c}\text { Water-saving } \\
\text { devices }\end{array}$ & 15 & & & Humidity & 10 & & \\
\hline & & & & & & Air quality & 10 & & \\
\hline Total: & 35 & & 45 & & 20 & & 40 & & 25 \\
\hline
\end{tabular}




\subsubsection{FIRST STAGE. Construction Stage}

The score assigned to each item was established based on information from existing sources (LEED ${ }^{\circledR}$ [36-41], CONAVI [42], Martija Martínez [43], Rodriguez [44], Masera [45], MESMIS [46-48]) and by consensus of several collegiate works. Sustainability indicators are shown in Tables 1 and 2. Using the score obtained from the evaluation of each prototype, a ratio was made in the percentage of sustainability, thus obtaining a comparable figure.

\subsubsection{SECOND STAGE. Performance of the Inhabited House}

Incises $\mathrm{A}$ and $\mathrm{E}$ are related to energy and, together, there are 60 points that are higher than the 45 points for water given the greater importance to energy. Energy was split in A and $\mathrm{E}$ to differentiate efficiency and emissions related to energy consumption.

A quantitative assessment of sustainability is shown in Figure 3, in which the weight of different sustainability characteristics can be seen in the evaluation of the housing. In this work, the sustainability assessment methodology was applied in consideration of the first stage (construction stage) only, because the house was not inhabited and did not meet all the requirements of a house.
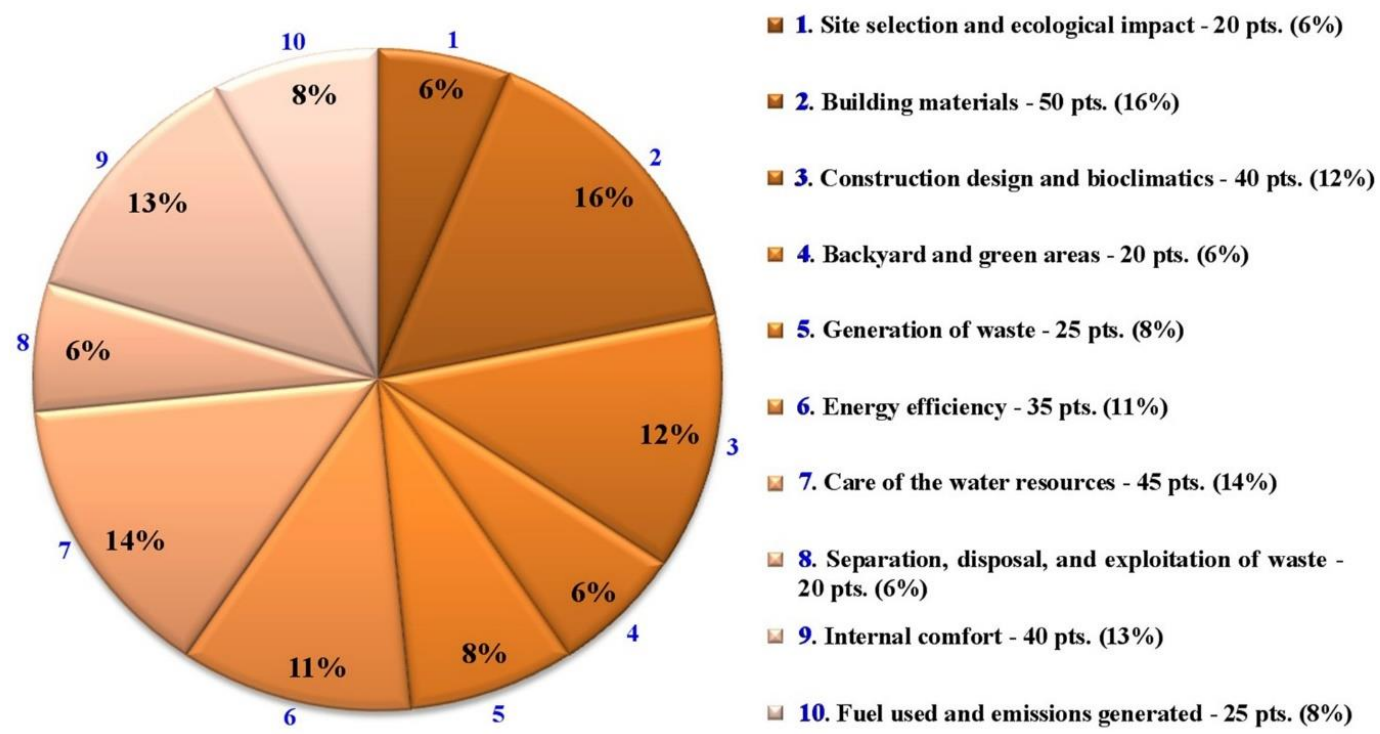

Figure 3. Indicators of sustainability and percentage contributed by each item.

\subsection{Sustainability Indicators}

Figure 3 shows in detail the contribution of each section to the degree of housing sustainability, with a total of 320 points equivalent to $100 \%$ sustainability. In this evaluation proposal, a format for evaluating housing sustainability is used that utilizes the antecedents of methodologies previously proposed in the literature.

\subsection{Building the Prototype with PET Bottles}

Figure 4 shows the images of the building process for the housing prototype in which PET bottles were used for both the walls and the roof. There were also other waste materials employed in the construction. The foundations used concrete pieces obtained from the demolition of a building. The bottles were filled with sand obtained from the excavation of the foundations, but the façade wall was installed using empty PET bottles without screw caps. This was to avoid deformations by temperature changes during the year, which occurred in stacked PET bottles. The result was a greatly simplified work, because the filling of the bottles was difficult. There was no significant difference between the façade and the other three walls in terms of stability, humidity accumulation or temperature transference. 

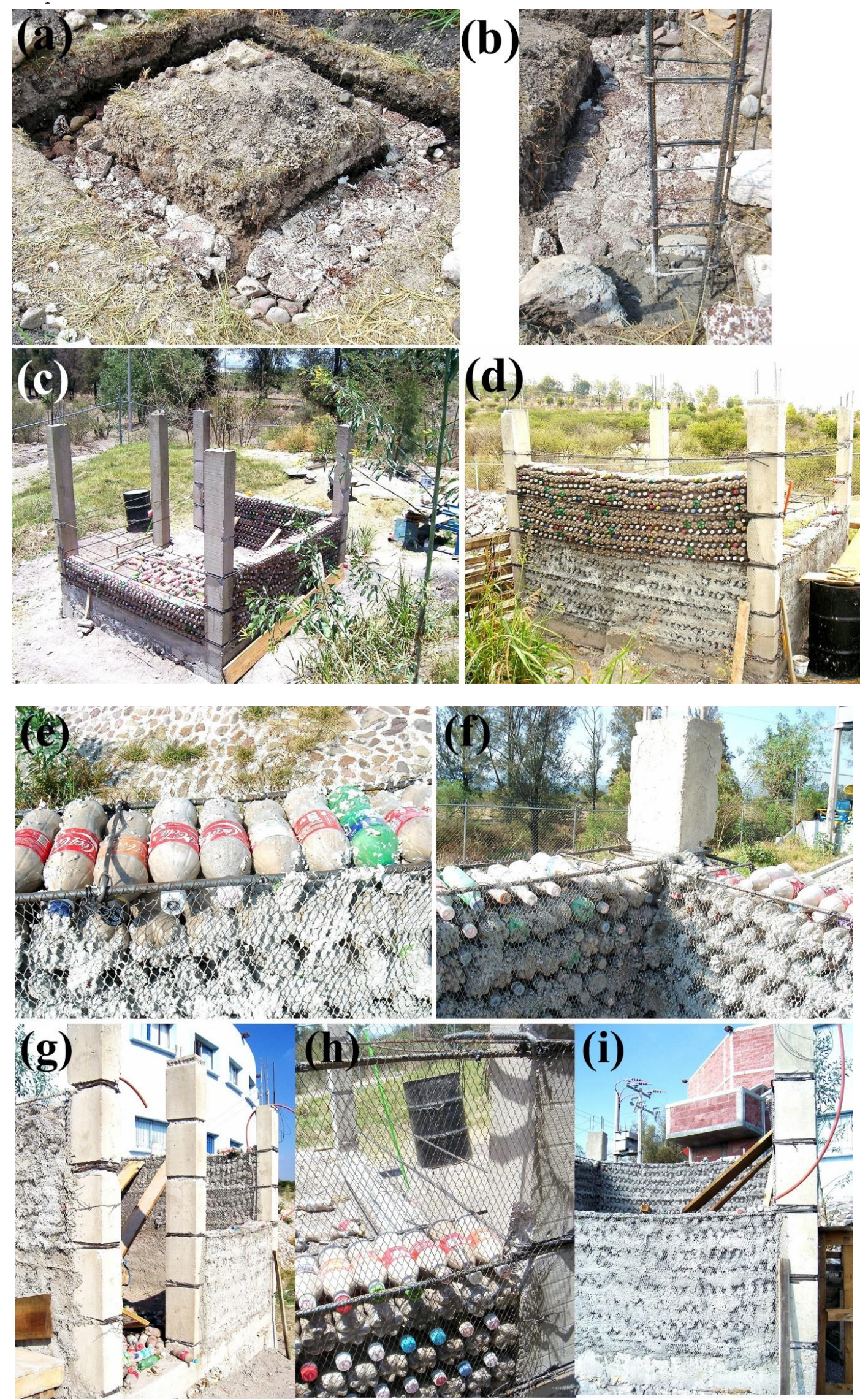

Figure 4. Cont. 

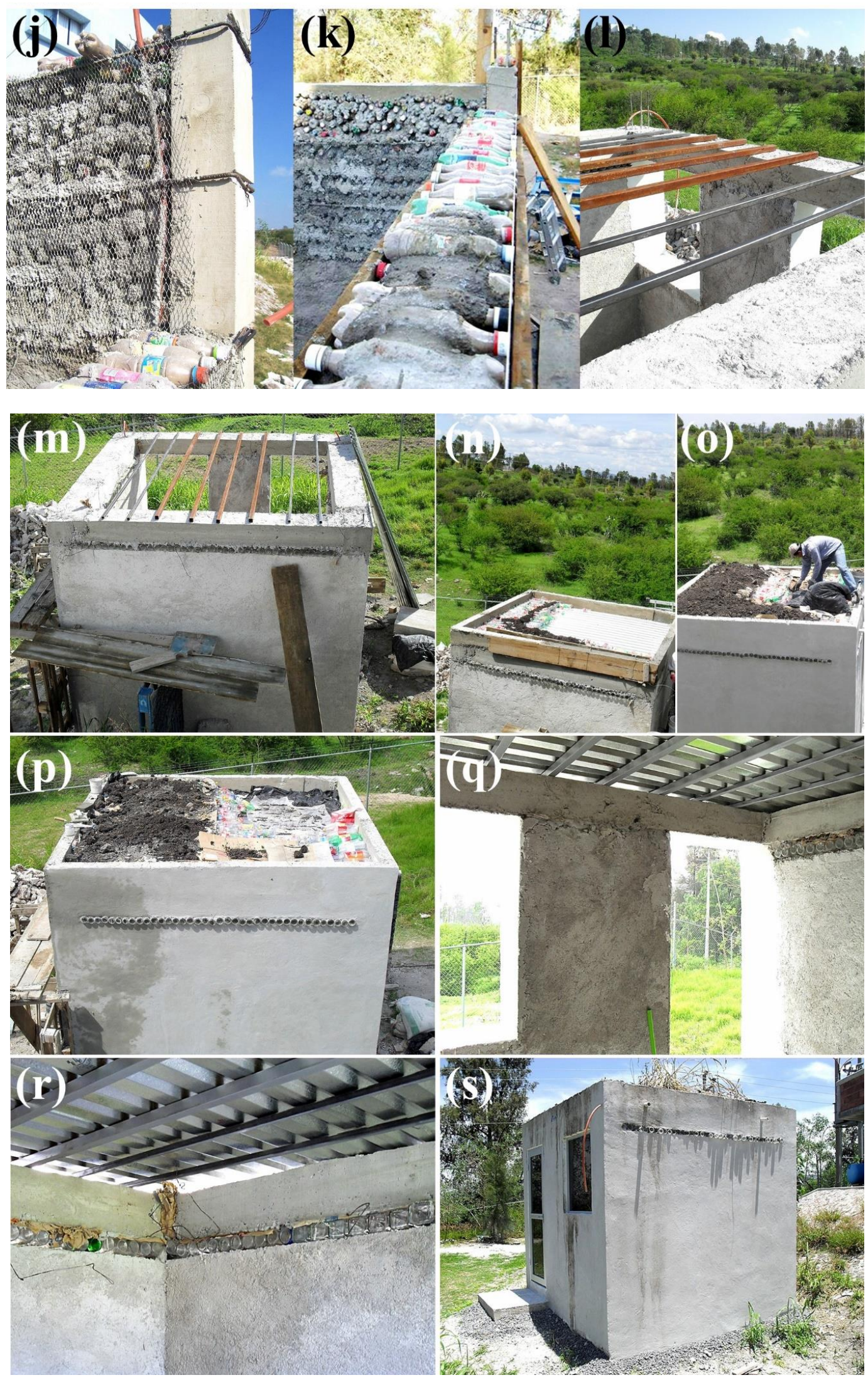

Figure 4. (a-s) Images of the building process for the housing prototype using PET bottles. 
The tubes for the electric cables were inserted under the metallic mesh. The ceiling was built with steel bars and galvanized sheets. Steel rebars were used every $1.2 \mathrm{~m}$ around the building to truss the mesh and the columns.

The multilayered roof was made of different waste materials and finished with a vegetation coverage (green roof). This roof fulfilled the desired characteristics of thermal insulation, waterproofing for rainy seasons and a top view similar to the surrounding area.

In addition, recycled glass bottles were placed on the inside top under the roof along the perimeter of the room to function as skylights. The space between the placed bottles was not sealed, with the objective of ventilating the lower part of the roof; this was because, in this area, the temperature is higher, and the air renewal cups would help with the reduction of the internal temperature.

\subsection{Simulation}

A first thermal simulation was performed considering only extreme conditions of external temperatures, and this was coupled to that observed in the real prototype related to the wall temperatures. It should be noted that the solar radiation phenomenon was not applied for this preliminary simulation. The temperature of the external medium was taken as $42{ }^{\circ} \mathrm{C}$, establishing, in turn, a ceiling temperature of $60^{\circ} \mathrm{C}$. The walls reached outside temperatures of about $30^{\circ} \mathrm{C}$. The doors and windows were at temperatures about $45^{\circ} \mathrm{C}$. In Figure 5, the internal temperature reached was about $25^{\circ} \mathrm{C}$.

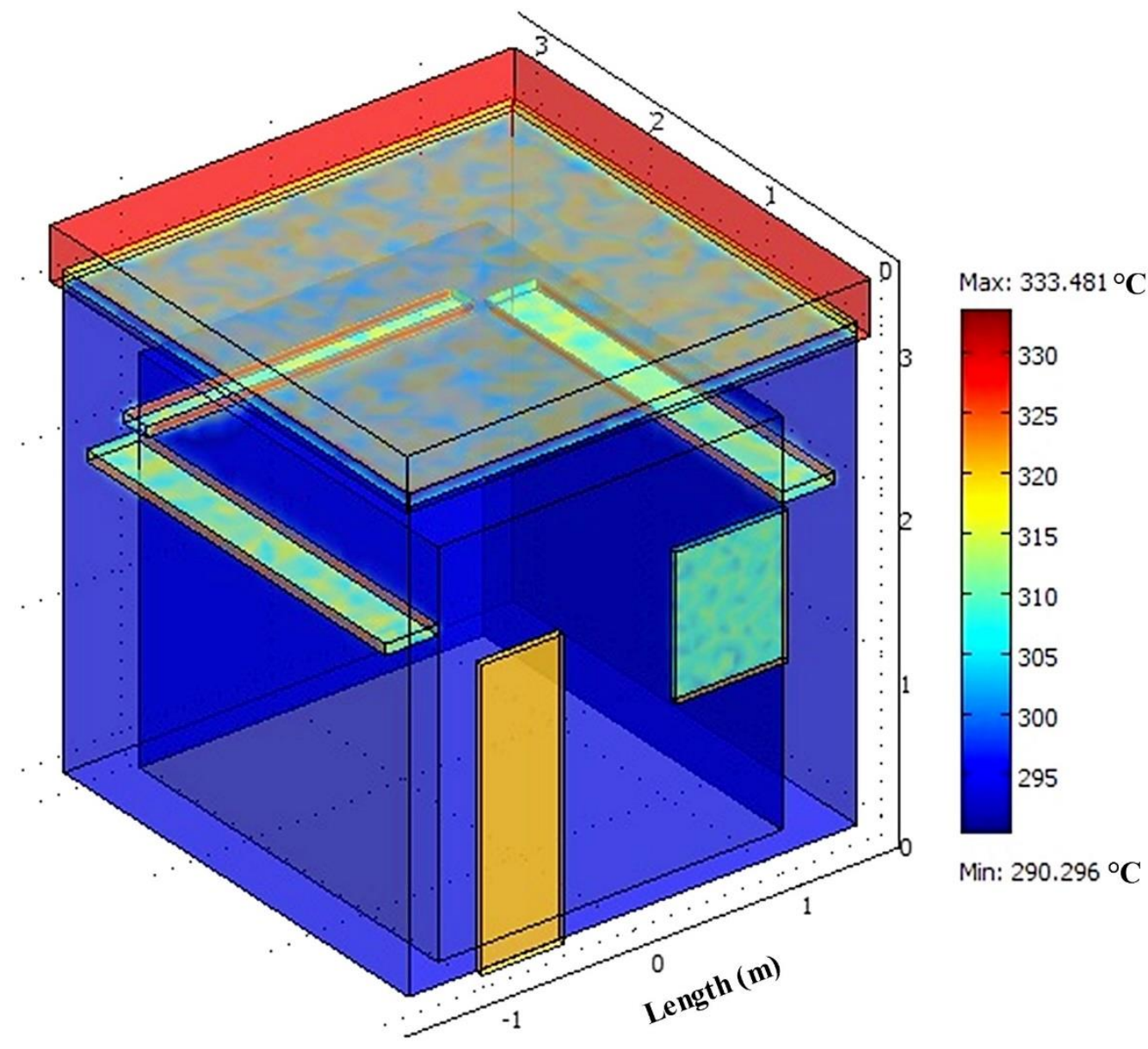

Figure 5. Thermal simulation of the internal behavior of the PET prototype, using the external temperature data from the real prototype. 
Figure 5 shows a maximum temperature of $44.65^{\circ} \mathrm{C}$ in the upper part of the house, and a minimum temperature of $36^{\circ} \mathrm{C}$, showing a stable behavior and a small variation in temperature. At the base of the building, different temperatures were observed, according to the initial conditions and contacts with the structure.

\subsection{External Measurement of the Prototype}

Thermographic images of the constructed prototype, with walls made using PET bottles, were taken (CIDETEQ, Qro., México), and a stable external behavior was observed in the different areas. In Figure $6 b$, a thermographic image of the prototype room façade is shown. The colder parts, shown in dark colors, are the window and the glasses that are part of the door, preventing the direct entrance of solar radiation and maintaining a temperature of about $45^{\circ} \mathrm{C}$ in the external walls.
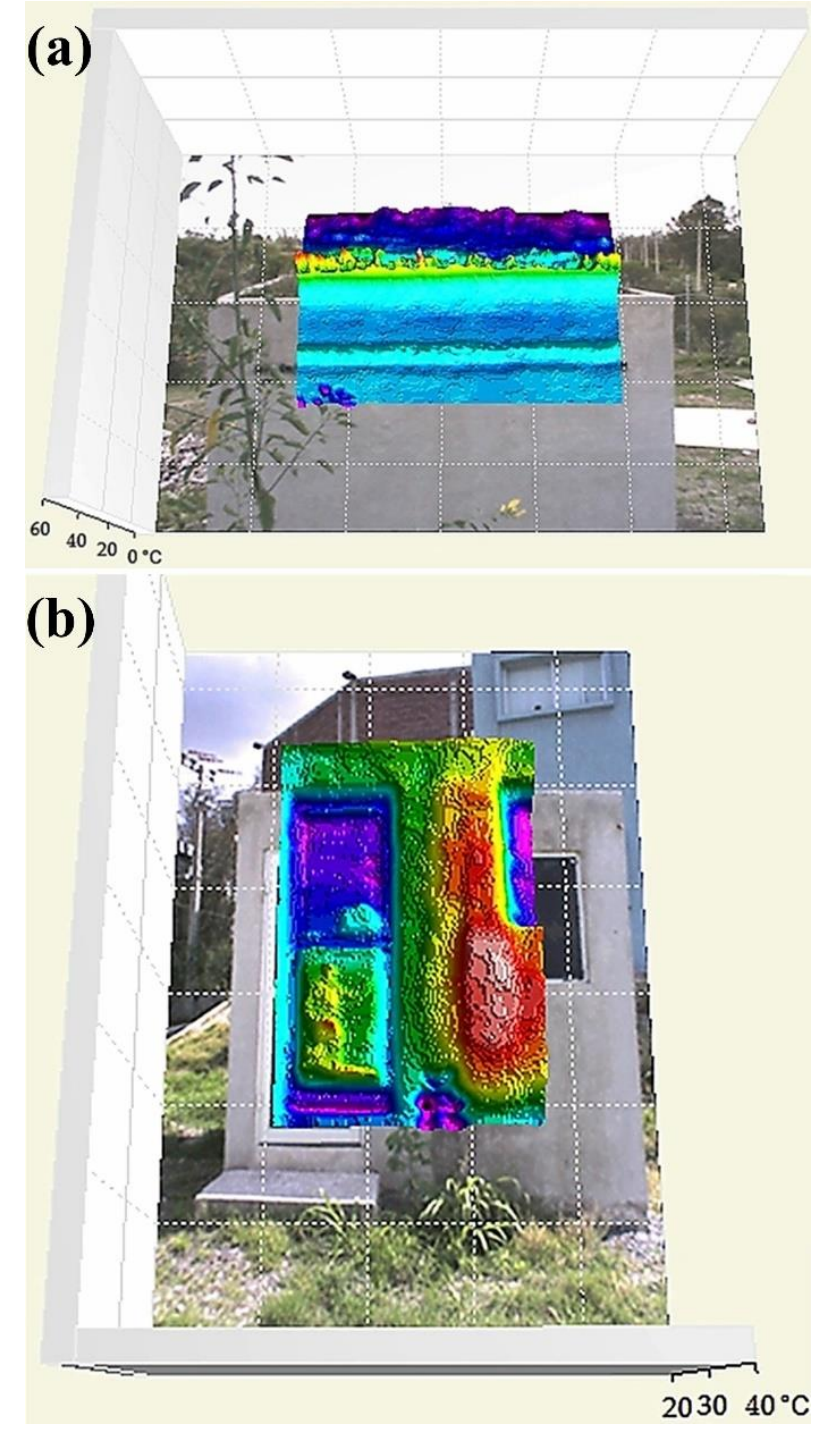

Figure 6. Thermograph image: (a) rear view and (b) façade view. 
Figure 6a shows a thermographic image taken from the rear section of the prototype, where the average temperature was also observed to be $45^{\circ} \mathrm{C}$. This temperature was very similar to that of the façade, which received a higher amount of solar radiation. The red and white spots indicate higher temperatures. This is due to variations in the structure originating in the construction stage, where the proportions of the material of the coating mixture are probably different in the white side area. Thermographs were taken in July, which usually is a warm month in the area. The external environmental temperature was $27.8^{\circ} \mathrm{C}$ at the time the thermographs were taken. This indicates the accumulation of heat in the external walls. In Figure 6a, the thermograph shows part of the roof and part of the external area of the wall from behind the building. It is possible to see a line in the lower part of this thermograph that is associated with a line of recycled glass bottles used on three sides as skylights of the room to provide daylight and passive ventilation.

The similarity in the temperature of the roof with that of the floor surrounding the structure was outstanding. This was caused by the use of site soil. The endemic plants, being seasonal, were not present at the time of taking the image, neither on the ceiling nor on the floor. One of the goals of green roofs is to mimic the surroundings, which was achieved by envisioning a superior perspective of the prototype room. Another objective of green roofs is to attenuate the heat island effect in urban areas, which is achieved by the addition of plants. In the case of the prototype, this last objective was fulfilled in the summer and autumn, when there is foliage on the top area.

\subsection{Internal Monitoring of the Prototype}

The humidity and thermal sensors were placed in two internal parts of the prototype, one of them close to one side of the window and the other in the lower part of the prototype, with the precaution that they should not, at any moment, receive direct solar radiation. A pair of sensors were placed as references under the shed with ventilation in nearby places. Once installed, the monitoring of temperature and humidity was carried out for about one month between February and March. During that time, the ventilation of the prototype remained open. It is worth mentioning that these were winter months with low temperatures.

Figure 7 shows the different temperatures and humidities obtained during the evaluation period. The zigzag lines indicate high and low points, representing one-day cycles between each peak, while more uniform lines represent the daily average of both temperature and humidity. As a control, a reference site was selected, which was an open area with a roof but without walls (sensors were protected from rain and direct sunlight). Figure 7a shows the temperature and humidity of the reference site, while Figure $7 \mathrm{~b}$ shows those of the PET housing prototype. These graphs indicate that temperature and humidity varied widely. The average daily variation was about $10.3^{\circ} \mathrm{C}$ and $30.4 \%$ relative humidity $(\mathrm{RH})$, respectively.

In Figure 7a, more controlled temperatures and humidity were observed, indicating an adequate performance of the prototype for these two measured parameters. The average daily temperature and humidity variations were $1.98{ }^{\circ} \mathrm{C}$ and $13.8 \% \mathrm{RH}$, in the case of the PET prototype.

Figure 7c shows the average temperature and humidities without the daily data of both the evaluated prototype and the reference site. In these graphs, it is observed that the average temperature of the prototype follows the same trend as the temperature of the site, only with smaller magnitudes. Similarities were found in the lines of humidity, but on the contrary, both the internal temperature and humidity were greater than the external. Regarding the general behavior of temperature and humidity, a high contrast between these two measurements was observed; as the humidity decreased, the temperature tended to increase, and vice versa. 

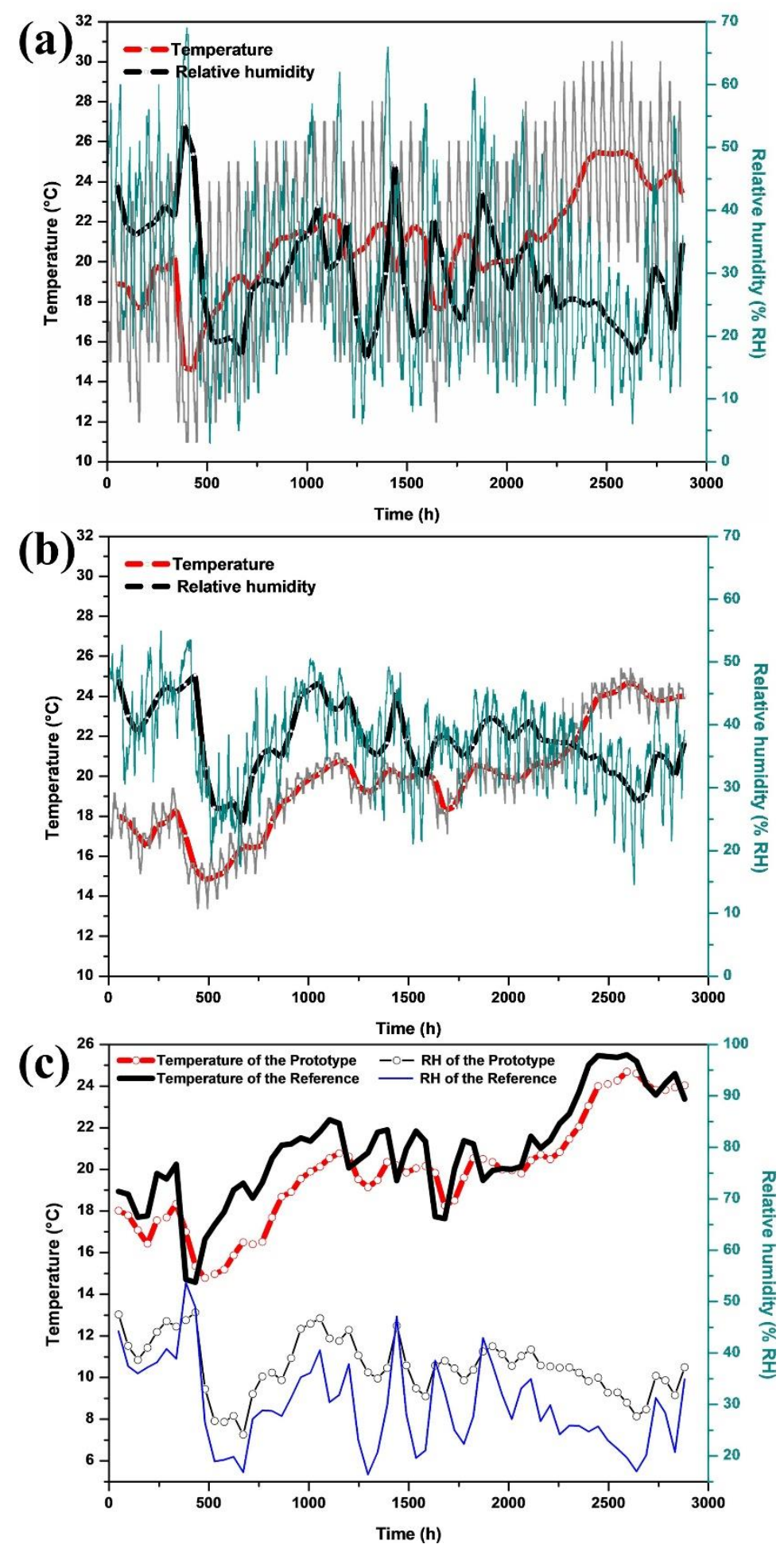

Figure 7. Temperature and humidity as a function of time at (a) the reference site and (b) the PET housing prototype; (c) average values without the daily data.

\subsection{The Degree of Sustainability of the Built Prototype}

The evaluation of the prototype's degree of sustainability was carried out, considering only the construction stage (the prototype was not inhabited), thus obtaining a total of 105 points out of 155 possible for the first stage (Table 3 ). With this, $67.74 \%$ sustainability was achieved for the housing, 
according to the methodology developed (which represents only the construction stage). In Table 3, the numbers in bold/italic are those in which the prototype did not fulfill the parameters.

Table 3. Detailed prototype sustainability assessment for the construction phase.

\begin{tabular}{ccc}
\hline FACTORS & Prototype & Ideal \\
\hline Respect the surrounding flora and fauna & 10 & 10 \\
\hline The ground meets the construction characteristics & 5 & 5 \\
\hline There is permission for the use of land for housing construction & 5 & 5 \\
\hline Materials adjacent to the site & 10 & 10 \\
\hline Recycling materials & 15 & 15 \\
\hline Rapidly renewable materials & $\mathbf{0}$ & $\mathbf{1 5}$ \\
\hline Vernacular materials & $\mathbf{5}$ & $\mathbf{1 0}$ \\
\hline Ceiling height & $\mathbf{0}$ & $\mathbf{5}$ \\
\hline Roof tilt & $\mathbf{0}$ & $\mathbf{5}$ \\
\hline Orientation of housing & $\mathbf{5}$ & $\mathbf{1 0}$ \\
\hline Ventilation & 10 & 10 \\
\hline Natural lighting & 10 & 10 \\
\hline Vegetation around the house & 5 & 5 \\
\hline Tonsumable vegetables using composting & $\mathbf{0}$ & $\mathbf{1 5}$ \\
\hline Minimize the amount of waste & 25 & 25 \\
\hline Total & 105 & 155 \\
\hline
\end{tabular}

\section{Conclusions}

This work consisted of three aspects: a proposal for the quantitative measurement of sustainability for housing; the development of a prototype using PET construction for wall and roof assembly; the evaluation of the structure's temperature/humidity both real and using a simulation.

Different indicators were proposed for assessing sustainability as well as the assignment of quantitative values. In this case, the constructed prototype obtained a score of $67.74 \%$ on the proposed housing sustainability scale when considering only one construction stage. In other words, it obtained 105 points out of 155 possible.

Regarding the external behavior of the PET-bottle prototype, it can be concluded that it had a uniform external behavior, maintaining a temperature of about $45^{\circ} \mathrm{C}$ within the walls. However, the maximum internal temperature was $30^{\circ} \mathrm{C}$, which was lower than the reference temperature. This value was not affected by changing the incoming illumination by the door or window. It is, however, possible to affirm that there were excellent insulation properties (evaluated in the months May-July).

The internal behavior of the prototype built with PET bottles showed a low temperature of about $10^{\circ} \mathrm{C}$. This was because the ventilation was not covered, which was done deliberately to evaluate the lowest temperature value, and the cold air of the outside entered without restriction, causing low internal temperatures (evaluated during the months February-March). With the result provided by the sensors, we can conclude that the prototype built with PET bottles was thermally stable, since the average daily temperature of the prototype varied by a fifth compared to the fluctuation of the average temperature recorded in the area.

The internal humidity was maintained between $15 \%$ and $55 \%$ RH. In the external environment, the range was between $3 \%$ and $70 \% \mathrm{RH}$. There was a significant difference between the inner and outer environments. The ideal humidity range for inhabited housing were in the range of $35-65 \% \mathrm{RH}$. The prototype reached very low humidity because the ventilation was kept open and was highly related to the external humidity. 
The simulation presented a possible performance and thermal transfer in line with the characteristics of the initial conditions and the border conditions that were used for evaluation. However, there are still factors that were not included in this simulation, such as solar radiation heating, convection and conduction, to simulate situations more closely related to the actual behavior that the built prototype could represent. The external simulation of the prototype resembled the images obtained in the thermographs.

Author Contributions: Conceptualization, J.d.J.P.B.; Formal analysis, F.R.C.S. and J.L.R.A.; Funding acquisition, J.d.J.P.B.; Investigation, F.R.C.S., J.d.J.P.B., M.L.M.L. and J.L.R.A.; Methodology, M.E.P.R.; Software, R.R.J.; Supervision, J.d.J.P.B. and M.L.M.L.; Validation, A.M.-R.; Writing-review \& editing, F.R.C.S., J.d.J.P.B. and M.L.M.L.

Funding: This research was funded by CONACYT, grant numbers COAH-2006-C05-62059, QRO-2010-C02-149297, and QRO-2010-C02-149-326.

Acknowledgments: The authors want to thank Juan Mendoza García, Juan Pablo Pérez Ramos and Edain Belen Pérez Mendoza for their efforts valuable contributions to the prototype building. In addition, we want to thank M.C. Pablo Esau Hidalgo Pimentel for his helpful advice in conducting the thermal simulation.

Conflicts of Interest: The authors declare no conflict of interest.

\section{References}

1. Hadfield, P. Gimme shelter. New Sci. 2000, 2228, 4 .

2. Mun, K.; Choi, N. Properties of poly methyl methacrylate mortars with unsaturated polyester resin as a crosslinking agent. Constr. Build. Mater. 2008, 22, 2147-2152. [CrossRef]

3. Bribián, I.Z.; Capilla, A.V.; Usón, A.A. Life cycle assessment of building materials: Comparative analysis of energy and environmental impacts and evaluation of the eco-efficiency improvement potential. Build. Environ. 2011, 46, 1133-1140. [CrossRef]

4. Pacheco-Torgal, F.; Jalali, S. Nanotechnology: Advantages and drawbacks in the field of construction and building materials. Constr. Build. Mater. 2011, 25, 582-590. [CrossRef]

5. Pacheco-Torgal, F.; Jalali, S. Cementitious building materials reinforced with vegetable fibers: A review. Constr. Build. Mater. 2011, 25, 575-581. [CrossRef]

6. Pacheco-Torgal, F. Eco-efficient construction and building materials research under the EU Framework Programme Horizon 2020. Constr. Build. Mater. 2014, 51, 151-162. [CrossRef]

7. Hosseinijou, S.A.; Mansour, S.; Shirazi, M.A. Social life cycle assessment for material selection: A case study of building materials. Int. J. Life Cycle Assess. 2014, 19, 620-645. [CrossRef]

8. Sari, A. Thermal energy storage characteristics of bentonite-based composite PCMs with enhanced thermal conductivity as novel thermal storage building materials. Energy Convers. Manag. 2016, 117, $132-141$. [CrossRef]

9. Silvestre, J.; De Brito, J.; Pinheiro, M.D. Environmental impacts and benefits of the end-of-life of building materials-Calculation rules, results and contribution to a "cradle to cradle" life cycle. J. Clean. Prod. 2014, 66, 37-45. [CrossRef]

10. Javadian, A.; Smith, I.F.C.; Saeidi, N.; Hebel, D.E. Mechanical Properties of Bamboo Through Measurement of Culm Physical Properties for Composite Fabrication of Structural Concrete Reinforcement. Front. Mater. 2019, 6, 15. [CrossRef]

11. Wei, Y.; Ji, X.; Duan, M.; Li, G. Flexural performance of bamboo scrimber beams strengthened with fiber-reinforced polymer. Constr. Build. Mater. 2017, 142, 66-82. [CrossRef]

12. Li, J.; Lu, Y.; Wu, Z.; Bao, Y.; Xiao, R.; Yu, H.; Chen, Y. Durable, self-cleaning and superhydrophobic bamboo timber surfaces based on $\mathrm{TiO}_{2}$ films combined with fluoroalkylsilane. Ceram. Int. 2016, 42, 9621-9629. [CrossRef]

13. Barreca, F.; Tirella, V. A self-built shelter in wood and agglomerated cork panels for temporary use in Mediterranean climate areas. Energy Build. 2017, 142, 1-7. [CrossRef]

14. Barreca, F.; Fichera, C.R. Wall panels of Arundo donax L. for environmentally sustainable agriculture buildings: Thermal performance evaluation. J. Food Agric. Environ. 2013, 11, 1353-1357. 
15. Ouedraogo, M.; Dao, K.; Millogo, Y.; Aubert, J.-E.; Messan, A.; Seynou, M.; Zerbo, L.; Gomina, M. Physical, thermal and mechanical properties of adobes stabilized with fonio (Digitaria exilis) straw. J. Build. Eng. 2019, 23, 250-258. [CrossRef]

16. Zonno, G.; Aguilar, R.; Boroschek, R.; Lourenço, P.B. Experimental analysis of the thermohygrometric effects on the dynamic behavior of adobe systems. Constr. Build. Mater. 2019, 208, 158-174. [CrossRef]

17. Lovón, R.; Lovón, E. The Impact of Humidity on the Resistance of Historic Adobe Monuments. In Structural Analysis of Historical Constructions; Aguilar, R., Torrealva, D., Moreira, S., Pando, M.A., Ramos, L.F., Eds.; RILEM Bookseries; Springer Science and Business Media LLC: Berlin/Heidelberg, Germany, 2019; Volume 18, pp. 1959-1967.

18. Poon, C.; Yu, A.T.; Ng, L. On-site sorting of construction and demolition waste in Hong Kong. Resour. Conserv. Recycl. 2001, 32, 157-172. [CrossRef]

19. Naik, T.; Singh, S.; Huber, C.; Brodersen, B. Use of post-consumer waste plastics in cement-based composites. Cem. Concr. Res. 1996, 26, 1489-1492. [CrossRef]

20. Silva, D.; Betioli, A.; Gleize, P.; Roman, H.; Gomez, L.; Ribeiro, J.; Ribeiro, J.L. Degradation of recycled PET fibers in Portland cement-based materials. Cem. Concr. Res. 2005, 35, 1741-1746. [CrossRef]

21. Tawfik, M.E.; Eskander, S.B. Polymer Concrete from Marble Wastes and Recycled Poly(ethylene terephthalate). J. Elastomers Plast. 2006, 38, 65-79. [CrossRef]

22. Siddique, R.; Khatib, J.; Kaur, I. Use of recycled plastic in concrete: A review. Waste Manag. 2008, 28, 1835-1852. [CrossRef] [PubMed]

23. Marzouk, O.Y.; Dheilly, R.-M.; Quéneudéc, M. Valorization of post-consumer waste plastic in cementitious concrete composites. Waste Manag. 2007, 27, 310-318. [CrossRef]

24. Ochi, T.; Okubo, S.; Fukui, K. Development of recycled PET fiber and its application as concrete-reinforcing fiber. Cem. Concr. Compos. 2007, 29, 448-455. [CrossRef]

25. Soto Ramírez, G.V. Desarrollo de Tabique de Concreto Ligero con Residuos de PET. Master's Thesis, Autonomous University of Queretaro, Querétaro, México, 2011.

26. Castañeda, L.E.G. La Tierra: Un Recurso Para Investigar, Sensibilizar, Transferir y Actuar; CONAVI: Mexico city, Mexico, 2008.

27. Hischier, R.; Weidema, B.; Althaus, H.J.; Bauer, C.; Doka, G.; Dones, R.; Frischknecht, R.; Hellweg, S.; Humbert, S.; Jungbluth, N.; et al. Implementation of Life Cycle Impact Assessment Methods; Ecoinvent Report No. 3; Swiss Centre for Life Cycle Inventories: Dübendorf, Switzerland, 2010.

28. Schiavoni, S.; Sambuco, S.; Rotili, A.; D’Alessandro, F.; Fantauzzi, F. A nZEB housing structure derived from end of life containers: Energy, lighting and life cycle assessment. Build. Simul. 2017, 10, 165-181. [CrossRef]

29. Oyarzo, J.; Peuportier, B. Life cycle assessment model applied to housing in Chile. J. Clean. Prod. 2014, 69, 109-116. [CrossRef]

30. Evangelista, P.P.; Kiperstok, A.; Torres, E.A.; Gonçalves, J.P. Environmental performance analysis of residential buildings in Brazil using life cycle assessment (LCA). Constr. Build. Mater. 2018, 169, 748-761. [CrossRef]

31. Zhang, X.; Shen, L.; Zhang, L. Life cycle assessment of the air emissions during building construction process: A case study in Hong Kong. Renew. Sustain. Energy Rev. 2013, 17, 160-169. [CrossRef]

32. Ortiz, O.; Castells, F.; Sonnemann, G. Sustainability in the construction industry: A review of recent developments based on LCA. Constr. Build. Mater. 2009, 23, 28-39. [CrossRef]

33. Cabeza, L.F.; Rincón, L.; Vilarino, V.; Perez, G.; Castell, A. Life cycle assessment (LCA) and life cycle energy analysis (LCEA) of buildings and the building sector: A review. Renew. Sustain. Energy Rev. 2014, 29, 394-416. [CrossRef]

34. Soust-Verdaguer, B.; Llatas, C.; García-Martínez, A. Simplification in life cycle assessment of single-family houses: A review of recent developments. Build. Environ. 2016, 103, 215-227. [CrossRef]

35. BuHamdan, S.; Alwisy, A.; Barkokebas, B.; Bouferguene, A.; Al-Hussein, M. A multi-criteria lifecycle assessment framework for evaluating building systems design. J. Build. Eng. 2019, 23, 388-402. [CrossRef]

36. LEED $^{\circledR}$. LEED v4 for Building Design and Construction. 2018. Available online: https://www.usgbc.org/ resources/leed-v4-building-design-and-construction-current-version (accessed on 11 January 2019).

37. Azhar, S.; Carlton, W.A.; Olsen, D.; Ahmad, I. Building information modeling for sustainable design and LEED $^{\circledR}$ rating analysis. Autom. Constr. 2011, 20, 217-224. [CrossRef]

38. Awadh, O. Sustainability and green building rating systems: LEED, BREEAM, GSAS and Estidama critical analysis. J. Build. Eng. 2017, 11, 25-29. [CrossRef] 
39. Wu, P.; Song, Y.; Shou, W.; Chi, H.; Chong, H.-Y.; Sutrisna, M. A comprehensive analysis of the credits obtained by LEED 2009 certified green buildings. Renew. Sustain. Energy Rev. 2017, 68, 370-379. [CrossRef]

40. Suzer, O. Analyzing the compliance and correlation of LEED and BREEAM by conducting a criteria-based comparative analysis and evaluating dual-certified projects. Build. Environ. 2019, 147, 158-170. [CrossRef]

41. Maslesa, E.; Jensen, P.A.; Birkved, M. Indicators for quantifying environmental building performance: A systematic literature review. J. Build. Eng. 2018, 19, 552-560. [CrossRef]

42. CONAVI. Criterios e Indicadores Para los Desarrollos Habitacionales Sustentables en México. 2006. Available online: http://www.conavi.gob.mx/publicaciones (accessed on 21 March 2019).

43. Martija Martínez, M. Un Modelo Conceptual y Método de Medición de la Sustentabilidad; Simposio Internacional, Ciudad y Sostenibilidad; Universidad Nacional Andrés Bello: Santiago de Chile, Chile, 2009.

44. De Buen Rodríguez, O. Evaluación de la Sustentabilidad Ambiental en la Construcción y Administración de Edificios en México; Gobierno de Miéxico: Mexico City, Mexico, 2010.

45. Masera, O.; Astier, M.; López Ridaura, S. Sustentabilidad y Manejo de Recursos Naturales; Mundi-Prensa: Mexico City, México, 1999.

46. Speelman, E.N.; López-Ridaura, S.; Colomer, N.A.; Astier, M.; Masera, O.R. Ten years of sustainability evaluation using the MESMIS framework: Lessons learned from its application in 28 Latin American case studies. Int. J. Sustain. Dev. World Ecol. 2007, 14, 345-361. [CrossRef]

47. López-Ridaura, S. Evaluating the sustainability of complex socio-environmental systems. The MESMIS framework. Ecol. Indic. 2002, 2, 135-148. [CrossRef]

48. Roboredo, D.; Bergamasco, S.M.P.P.; Ara, A.; Gervázio, W.; Domingues, T.R. Managements systems clustering and sustainability indicators of construction using the methodology mesmis the territory Amazon portal. Reaga Espac. Geogr. Anal. 2018, 43, 23-42.

(C) 2019 by the authors. Licensee MDPI, Basel, Switzerland. This article is an open access article distributed under the terms and conditions of the Creative Commons Attribution (CC BY) license (http://creativecommons.org/licenses/by/4.0/). 